\title{
EKSTRAKSI FLA VONOID DARI DAUN PARE (MOMORDICA CHARANTIA L.) BERBANTU GELOMBANG MIKRO SEBAGAI PENURUN KADAR GLUKOSA SECARA IN VITRO
}

\author{
Erlita Verdia Mutiara ${ }^{1)}$, Achmad Wildan ${ }^{1)}$ \\ ${ }^{1)}$ Sekolah Tinggi Ilmu Farmasi "Yayasan Pharmasi" Semarang \\ Jl. Sarwo Edhie Wibowo Km.1 Plamongansari, Pucanggading, Semarang \\ Achmadwildan58@gmail.com
}

\begin{abstract}
One of the traditional medicinal plants are believed to be lowering glucose levels are pare (Momordica charantia L.). Plants pare (Momordica charantia L.) is a plant that is familiar to the people of Indonesia, because the fruit is often used as asvegetables. The pare leaf chemical constituents is alkaloids, flavonoids, saponins, and tannins that can be used as an antioxidant, antimicrobial, antidiabetic, antitumor, and antilepra. The main advantage of microwave-assisted extraction compared to conventional extraction using soxhlet namely greater efficiency and a shorter operating time. Microwave-assisted extraction will provide the transfer rate is higher than the conventional extraction.

This study aims to determine the ability of a flavonoid extract of the leaves of pare (Momordica charantia L.) in lowering glucose levels and maximum concentrations of the extract flavonoids that can lower glucose levels as well as the variation of the variable microwave extraction for obtaining extracts optimal results. The process of extracting flavonoids from the leaves of pare (Momordica charantia L.) is done using a microwave extractor with frequency $2450 \mathrm{MHz}$ with a maximum power of 900 watts. The extract obtained was then reacted with glucose with Nellson-Somogyi method. Types of flavonoids that play a role in lowering glucose levels were identified using a sliding reagent with UV-Vis spectrophotometer.

The results showed that the optimum conditions in the extraction process of flavonoids from the leaves of bitter melon (Momordica charantia L.) by microwave-assisted was the 30 minute with a yield of $20.85 \%$. The concentration of flavonoids extract can lower glucose levels are 160 ppm with a $50.38 \%$ decrease. Flavonoid compounds that play a role in lowering glucose levels in the leaves of pare is 5,3 ', 4'trihydroxy flavonols.
\end{abstract}

Keywords: extraction, microwaves, glucose, pare leaves, Nellson Somogyi

\begin{abstract}
Abstrak
Salah satu tanaman obat tradisional yang dipercaya sebagai penurun kadar glukosa adalah pare (Momordica charantiaL.). Tanaman pare (Momordica charantia L.) merupakan tanaman yang tidak asing bagi masyarakat Indonesia, karena buahnya sering digunakan sebagai sayuran atau lalapan. Kandungan kimia daun pare yaitu alkaloid, flavonoid, saponin, dan tanin yang dapat digunakan sebagai antioksidan, antimikroba, antidiabetes, antitumor, dan antilepra.Keuntungan utama dari ekstraksi dengan bantuan gelombang mikro dibandingkan dengan ekstraksi konvensional menggunakan sokhlet yaitu efisiensi lebih besar dan waktu operasinya lebih singkat. Ekstraksi berbantu gelombang mikro akan memberikan laju perpindahan masa yang lebih tinggi dibandingkan ekstraksi konvensional.

Penelitian ini bertujuan untuk mengetahui kemampuan dari ekstrak flavonoid dari daun pare (Momordica charantia L.) dalam menurunkan kadar glukosa dan konsentrasi maksimal dari ekstrak flavonoid yang dapat menurunkan kadar glukosa serta variasi dari variabel ekstraksi gelombang mikro untuk memperoleh hasil ekstrak yang optimal. Proses ekstraksi flavonoid dari daun pare(Momordica charantia L.) dilakukan menggunakan alat microwave ekstraktor dengan frekuensi $2450 \mathrm{Mhz}$ dengan daya maksimal 900 watt. Ekstrak yang diperoleh kemudian direksikan dengan glukosa dengan metode NellsonSomogyi. Jenis flavonoid yang berperan dalam menurunkan kadar glukosa diidentifikasi menggunakan pereaksi geser dengan spektrofotometer UV-Vis.

Hasil penelitian menunjukkan kondisi yang optimum dalam proses ekstraksi flavonoid dari daun pare (Momordica charantia L.) dengan berbantu gelombang mikro adalah menit ke-30 dengan rendemen 20,85\%. Konsentrasi ekstrak flavonoid yang dapat menurunkan kadar glukosa adalah 160 ppm dengan penurunan $50,38 \%$.
\end{abstract}


Senyawa flavonoid yang berperan dalam menurunkan kadar glukosa dalam daun pare adalah 5,3',4'trihidroksi flavonol.

Kata kunci : Ekstraksi, gelombang mikro,glukosa, daun pare, Nellson Somogyi

\section{PENDAHULUAN}

Diabetes mellitus adalah gangguan metabolik yang ditandai oleh hilangnya homeostasis glukosa akibat dari penurunan fungsi sekresi insulin, kerja insulin atau keduanya. Penurunan fungsi hormon insulin ini mengakibatkan seluruh gula (glukosa) yang dikonsumsi tubuh tidak dapat diproses sempurna sehingga kadar glukosa di dalam tubuh akan meningkat yang disebut hiperglikemia (Basha dan Kumari, 2012 : 1). Gejala awal diabetes mellitus dapat berupa sering kencing (poliuri), sering minum (polidipsi), dan sering makan (polifagi). Apabila keadaan tersebut tidak diatasi dapat menimbulkan komplikasi penyakit berbahaya. (Hardiman, 2013).

Salah satu tanaman obat tradisional yang dipercaya sebagai penurun kadar glukosa adalah pare (Momordica charantiaL.). Menurut Leelaprakash, dkk. (2011), kandungan kimia daun pare yaitu alkaloid, flavonoid, saponin, dan tanin. Penelitian yang dilakukan oleh Ahmad, dkk. (2012) menyatakan bahwa isolat biji pare dapat digunakan untuk menurunkan kadar glukosa secara in vitro. Penelitian ini menggunakan metode enzimatis. Prinsip metode tersebut adalah menghambat aktivitas enzim $\alpha$-glukosidase sehingga polisakarida tidak diubah menjadi glukosa. Hasil penelitian diperoleh bahwa isolat biji pare konsentrasi $2 \mathrm{mg} / \mathrm{dL}$ mampu menghambat enzim $\alpha$-glukosidase sebesar $79,18 \%$. Selain metode enzimatis, penurunan kadar glukosa secara in vitro dapat menggunakan metode Nellson-Somogyi.

Berdasarkan penelitian tersebut diatas, penelitian ini mengacu pada penelitian Ahmad, dkk. (2012), tetapi menggunakan daun pare dengan metode Nellson-Somogyi.

Daun pare digunakan karena sejauh ini belum ada penelitian mengenai daun pare sebagai antidiabetes. Penelitian ini menggunakan metode Nellson-Somogyi karena faktor pengganggu dari metode tersebut cenderung lebih mudah dikendalikan dibandingkan dengan metode enzimatis, selain itu bahan yang digunakan lebih mudah didapatkan. Prinsip metode Nellson-Somogyi adalah mengoksidasi glukosa menggunakan pereaksi Nellson, kemudian ditambahkan dengan larutan arsenomolibdat membentuk kompleks molibdenum yang berwarna biru kehijauan dan dapat diukur absorbansinya untuk menentukan kadar glukosa (Razak, 2012).

\section{METODE PENELITIAN}

Objek penelitian ini adalah penurunan kadar glukosa fraksi $n$-heksan, fraksi etil asetat, dan fraksi air ekstrak etanol daun pare (Momordica charantia L.) yang dinyatakan dengan persentase (\%) penurunan kadar glukosa.

Variabel terikat dalam penelitian ini berupa penurunan glukosa setelah pemberian fraksi ekstrak etanol daun pare (Momordica charantia L.).

Bahan penelitian meliputi serbuk daun pare (Momordica charantia L.), serbuk glukosa anhidrat, reagen Nellson, reagen arsenomolibdat, akuades, metanol, $\mathrm{NaOH}$, $\mathrm{AlCl}_{3}$, serbuk NaOAc, serbuk $\mathrm{H}_{3} \mathrm{BO}_{3}$.

Alat penelitian meliputi labu takar, pipet volume, corong kaca, pipet tetes, penangas air, spektrofotometer UV-Vis Shimadzu 1700 series.

Maserasi serbuk daun pare sebanyak 50,0 gram ditambah etanol 70\% sepuluh kali berat serbuk. Perendaman dilakukan selama 5 hari pada suhu ruang dan terlindung dari cahaya.Setiap hari dilakukan pengadukan,

Kemudian disaring, dan diganti pelarut etanol $70 \%$ baru dengan jumlah yang sama. Filtrat yang dihasilkan dijadikan satu kemudian disaring. Filtrat dikumpulkan dan dipekatkan di atas penangas air pada suhu $70^{\circ} \mathrm{C}$ sampai diperoleh ekstrak kental (Purwatresna, 2012). 


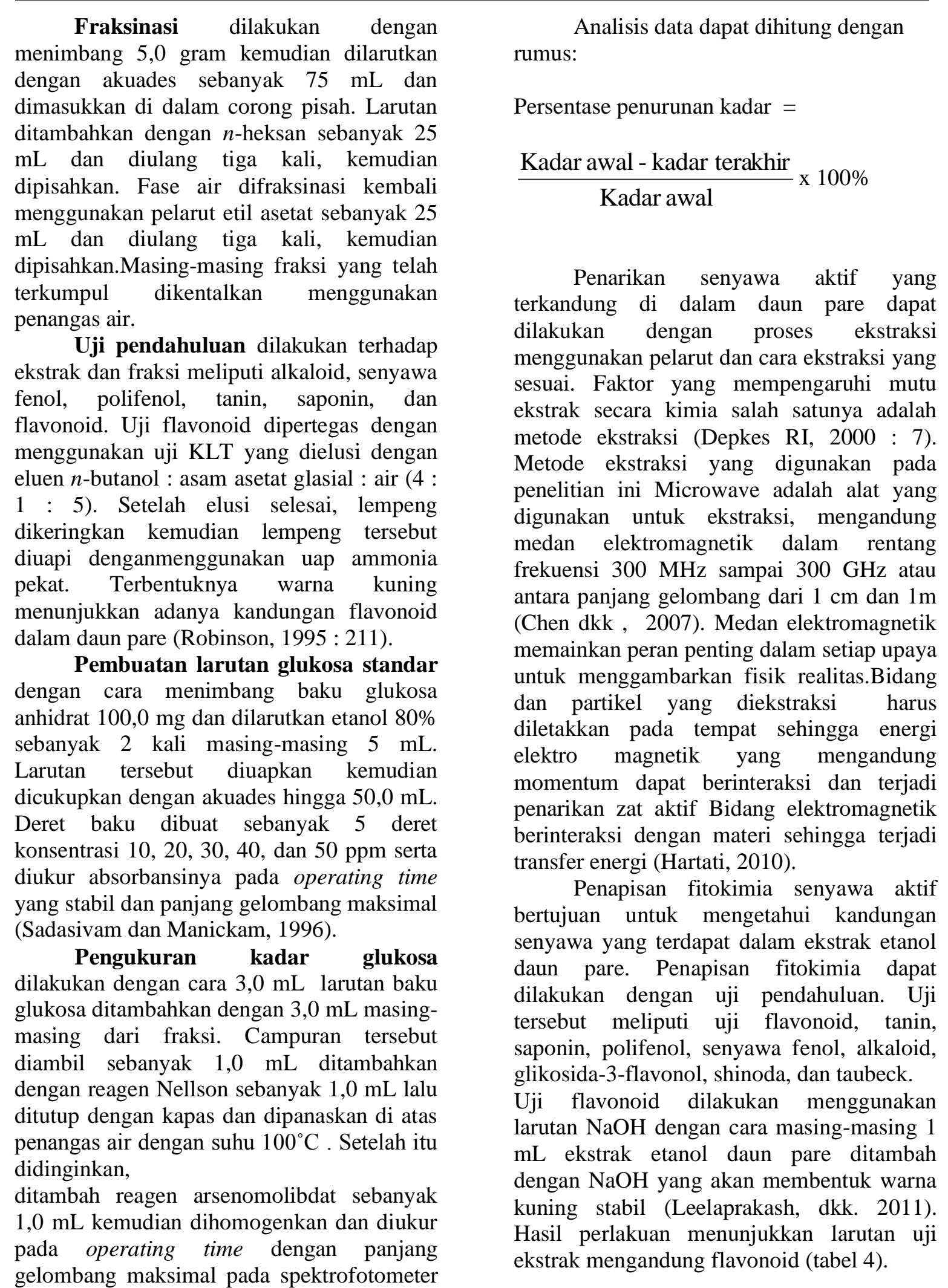
visibel (Ermaiza, 2009). 
EKSTRAKSI FLAVONOID DARI DAUN PARE....

(Erlita dkk)

Tabel 4. Hasil Uji Senyawa Flavonoid

\begin{tabular}{|l|l|l|}
\hline \multicolumn{1}{|c|}{$\begin{array}{c}\text { Larutan } \\
\text { Uji }\end{array}$} & \multicolumn{1}{|c|}{$\begin{array}{c}\text { Hasil } \\
\text { Perlakuan }\end{array}$} & Keterangan \\
\hline $\begin{array}{l}\text { Rutin } \\
\text { (Kontrol } \\
\text { positif) }\end{array}$ & $\begin{array}{l}\text { Larutan } \\
\text { kuning }\end{array}$ & $\begin{array}{l}\text { Mengandung } \\
\text { flavonoid }\end{array}$ \\
\hline $\begin{array}{l}\text { Akuades } \\
\text { (Kontrol } \\
\text { negatif) }\end{array}$ & $\begin{array}{l}\text { Larutan } \\
\text { jernih }\end{array}$ & $\begin{array}{l}\text { Tidak } \\
\text { mengandung } \\
\text { flavonoid }\end{array}$ \\
\hline Ekstrak & $\begin{array}{l}\text { Larutan } \\
\text { kuning pekat }\end{array}$ & $\begin{array}{l}\text { Mengandung } \\
\text { flavonoid }\end{array}$ \\
\hline
\end{tabular}

Pendahuluan glikosida-3-flavonol menunjukkan hasil positif pada ekstrak, Menurut Depkes RI (1995), uji glikosida-3flavonol menunjukkan hasil positif apabila setelah penambahan pereaksi dalam waktu 2 sampai 5 menit tidak terjadi warna kuning (tabel 5).

Tabel 5.Pendahuluan Glikosida-3-flavonol

\begin{tabular}{|l|l|l|}
\hline Larutan Uji & $\begin{array}{c}\text { Hasil } \\
\text { Perlakuan }\end{array}$ & \multicolumn{1}{|c|}{ Keterangan } \\
\hline $\begin{array}{l}\text { Rutin } \\
\text { (kontrol } \\
\text { positif) }\end{array}$ & $\begin{array}{l}\text { Merah } \\
\text { muda }\end{array}$ & $\begin{array}{l}\text { Mengandung } \\
\text { Glikosida-3- } \\
\text { flavonol }\end{array}$ \\
\hline $\begin{array}{l}\text { Akuades } \\
\text { kontrol } \\
\text { negatif) }\end{array}$ & $\begin{array}{l}\text { Larutan } \\
\text { jernih }\end{array}$ & $\begin{array}{l}\text { Tidak } \\
\text { mengandung } \\
\text { Glikosida-3- } \\
\text { flavonol }\end{array}$ \\
\hline Ekstrak & Hijau & $\begin{array}{l}\text { Mengandung } \\
\text { Glikosida-3- } \\
\text { flavonol }\end{array}$ \\
\hline
\end{tabular}

Uji Shinoda menunjukkan hasil negatif pada ekstrak,. Menurut Depkes RI (1995), uji shinoda menunjukkan hasil positif flavon, khalkon, dan auron apabila setelah penambahan pereaksi terjadi warna kuning, sehingga di dalam ekstrak tidak mengandung flavonoid golongan flavon, khalkon, dan auron. (tabel 6).
Tabel 6.Uji Shinoda

\begin{tabular}{|l|l|l|}
\hline $\begin{array}{c}\text { Larutan } \\
\text { Uji }\end{array}$ & $\begin{array}{c}\text { Hasil } \\
\text { Perlakuan }\end{array}$ & Keterangan \\
\hline $\begin{array}{l}\text { Rutin } \\
\text { (kontrol } \\
\text { positif) }\end{array}$ & $\begin{array}{l}\text { Larutan } \\
\text { kuning }\end{array}$ & $\begin{array}{l}\text { Mengandung } \\
\text { shinoda }\end{array}$ \\
\hline $\begin{array}{l}\text { Akuades } \\
\text { (kontrol } \\
\text { negatif) }\end{array}$ & $\begin{array}{l}\text { Larutan } \\
\text { jernih }\end{array}$ & $\begin{array}{l}\text { Tidak } \\
\text { mengandung } \\
\text { shinoda }\end{array}$ \\
\hline Ekstrak & Hijau & $\begin{array}{l}\text { Tidak } \\
\text { mengandung } \\
\text { flavon, } \\
\text { kalkon dan } \\
\text { auron }\end{array}$ \\
\hline
\end{tabular}

Uji Taubeck menunjukkan hasil positif pada ekstrak. Menurut Depkes RI (1995), uji taubeck menunjukkan hasil positif apabila setelah penambahan reaksi larutan uji berfluoresensi kuning intensif dibawah sinar UV 254 menunjukkan adanya flavonoid (tabel 7).

Tabel 7.Pendahuluan Flavonoid Taubeck

\begin{tabular}{|l|l|l|}
\hline $\begin{array}{c}\text { Larutan } \\
\text { Uji }\end{array}$ & \multicolumn{1}{|c|}{$\begin{array}{c}\text { Hasil } \\
\text { Perlakuan }\end{array}$} & Keterangan \\
\hline $\begin{array}{l}\text { Akuades } \\
\text { (kontrol } \\
\text { negatif) }\end{array}$ & $\begin{array}{l}\text { Tidak } \\
\text { berpendar } \\
\text { kuning }\end{array}$ & $\begin{array}{l}\text { Tidak } \\
\text { mengandung } \\
\text { flavono }\end{array}$ \\
\hline Ekstrak & $\begin{array}{l}\text { Berpendar } \\
\text { kuning }\end{array}$ & $\begin{array}{l}\text { Mengandung } \\
\text { flavonoid }\end{array}$ \\
\hline
\end{tabular}

Identifikasi tanin dilakukan menggunakan larutan $\mathrm{FeCl}_{3} 1 \%$ dengan cara masing-masing $1 \mathrm{~mL}$ ekstrak etanol daun pare ditambah larutan $\mathrm{FeCl} 31 \%$ akan membentuk warna hijau kehitaman atau biru tua (tabel 8) (Depkes RI, 1995). 
METANA, Vol. 10 No.01, Juli 2014, Hal. 1-11

Tabel 8. Hasil Uji Senyawa Tanin

\begin{tabular}{|l|l|l|}
\hline Larutan Uji & $\begin{array}{c}\text { Hasil } \\
\text { perlakuan }\end{array}$ & \multicolumn{1}{|c|}{ Keterangan } \\
\hline $\begin{array}{l}\text { Larutan } \\
\text { gambir } \\
\text { (kontrol } \\
\text { positif) }\end{array}$ & Biru tua & $\begin{array}{l}\text { Mengandung } \\
\text { senyawa tanin }\end{array}$ \\
\hline $\begin{array}{l}\text { Akuades } \\
\text { (kontrol } \\
\text { negatif) }\end{array}$ & Oranye & $\begin{array}{l}\text { Tidak } \\
\text { mengandung } \\
\text { senyawa tanin }\end{array}$ \\
\hline Ekstrak & Hijau & $\begin{array}{l}\text { Mengandung } \\
\text { senyawa tanin }\end{array}$ \\
\hline
\end{tabular}

Identifikasi saponin dilakukan menggunakan pemanasan masing-masing $1 \mathrm{~mL}$ ekstrak dan fraksi ekstrak etanol daun pare, kemudian dikocok vertikal akan membentuk busa. Busa yang terbentuk akan stabil setelah penambahan $\mathrm{HCl} \mathrm{1 \%}$ (tabel 9) (Depkes RI, 1995).

Tabel 9. Hasil Uji Senyawa Saponin

\begin{tabular}{|l|l|l|}
\hline \multicolumn{1}{|c|}{$\begin{array}{c}\text { Larutan } \\
\text { Uji }\end{array}$} & $\begin{array}{c}\text { Hasil } \\
\text { Perlakuan }\end{array}$ & Keterangan \\
\hline $\begin{array}{l}\text { Larutan } \\
\text { lerak } \\
\text { (kontrol } \\
\text { positif) }\end{array}$ & Berbusa & $\begin{array}{l}\text { Mengandung } \\
\text { senyawa } \\
\text { saponin }\end{array}$ \\
\hline $\begin{array}{l}\text { Akuades } \\
\text { kontrol } \\
\text { negatif) }\end{array}$ & $\begin{array}{l}\text { Tidak } \\
\text { berbusa }\end{array}$ & $\begin{array}{l}\text { Tidak } \\
\text { mengandung } \\
\text { senyawa } \\
\text { saponin }\end{array}$ \\
\hline Ekstrak & Berbusa & $\begin{array}{l}\text { Mengandung } \\
\text { senyawa } \\
\text { saponin }\end{array}$ \\
\hline
\end{tabular}

Identifikasi polifenol dilakukan dengan cara masing-masing $1 \mathrm{~mL}$ ekstrak dan fraksi ekstrak etanol daun pare ditambah dengan 1 $\mathrm{mL}$ larutan kalium heksasianoferat (III) dan 1 $\mathrm{mL}$ larutan besi (III) klorida $1 \%$ menunjukkan warna biru prusian (tabel 10) (Depkes RI, 1995).
Tabel 10. Hasil Uji Senyawa Polifenol

\begin{tabular}{|l|l|l|}
\hline \multicolumn{1}{|c|}{$\begin{array}{c}\text { Larutan } \\
\text { Uji }\end{array}$} & \multicolumn{1}{c|}{$\begin{array}{c}\text { Hasil } \\
\text { Perlakuan }\end{array}$} & Keterangan \\
\hline $\begin{array}{l}\text { Larutan } \\
\text { resorcinol } \\
\text { (kontrol } \\
\text { positif) }\end{array}$ & Biru prusian & $\begin{array}{l}\text { Mengandung } \\
\text { senyawa } \\
\text { polifenol }\end{array}$ \\
\hline $\begin{array}{l}\text { Akuades } \\
\text { kontrol } \\
\text { negatif) }\end{array}$ & Biru terang & $\begin{array}{l}\text { Tidak } \\
\text { mengandung } \\
\text { senyawa } \\
\text { polifenol }\end{array}$ \\
\hline Ekstrak & Biru prusian & $\begin{array}{l}\text { Mengandung } \\
\text { senyawa } \\
\text { polifenol }\end{array}$ \\
\hline
\end{tabular}

Identifikasi alkaloid dilakukan dengan cara $1 \mathrm{~mL}$ ekstrak etanol daun pare ditambah $1 \mathrm{~mL}$ larutan $\mathrm{HCl} 2 \mathrm{~N}$ dan akuades, kemudian dipanaskan, kemudian didinginkan dan disaring. Filtrat yang diperoleh ditambah reagen dragendrof. Terbentuknya warna merah cokelat menunjukkan adanya senyawa alkaloid (tabel 11) (Depkes RI, 1995).

\section{Tabel 11. Hasil Uji Senyawa Alkaloid}

\begin{tabular}{|l|l|l|}
\hline $\begin{array}{c}\text { Larutan } \\
\text { Uji }\end{array}$ & \multicolumn{1}{c|}{$\begin{array}{c}\text { Hasil } \\
\text { Perlakuan }\end{array}$} & \multicolumn{1}{|c|}{ Keterangan } \\
\hline $\begin{array}{l}\text { Larutan } \\
\text { kafein } \\
\text { (kontrol } \\
\text { positif) }\end{array}$ & $\begin{array}{l}\text { Merah } \\
\text { cokelat }\end{array}$ & $\begin{array}{l}\text { Mengandung } \\
\text { senyawa alkaloid }\end{array}$ \\
\hline $\begin{array}{l}\text { Akuades } \\
\text { (kontrol } \\
\text { negatif) }\end{array}$ & Merah & $\begin{array}{l}\text { Tidak } \\
\text { mengandung } \\
\text { senyawa alkaloid }\end{array}$ \\
\hline Ekstrak & $\begin{array}{l}\text { Merah } \\
\text { cokelat }\end{array}$ & $\begin{array}{l}\text { Mengandung } \\
\text { senyawa alkaloid }\end{array}$ \\
\hline
\end{tabular}

Identifikasi senyawa fenol dilakukan dengan cara masing-masing fraksi $n$-heksan, fraksi etil asetat, fraksi air, dan ekstrak etanol daun pare (Momordica charantia L.) diambil sebanyak $1 \mathrm{~mL}$ kemudian ditambah dengan 1 $\mathrm{mL}$ larutan besi (III) klorida $1 \%$. Terbentuknya warna merah, ungu, biru, dan hitam menunjukkan adanya senyawa fenol (tabel 12) (Depkes RI, 1995). 
Tabel 12. Hasil Uji Senyawa Fenol

\begin{tabular}{|l|l|l|}
\hline Larutan Uji & $\begin{array}{c}\text { Hasil } \\
\text { Perlakuan }\end{array}$ & Keterangan \\
\hline $\begin{array}{l}\text { Larutan } \\
\text { phenol } \\
\text { (kontrol } \\
\text { positif) }\end{array}$ & Ungu & $\begin{array}{l}\text { Mengandung } \\
\text { senyawa fenol }\end{array}$ \\
\hline $\begin{array}{l}\text { Akuades } \\
\text { (kontrol } \\
\text { negatif) }\end{array}$ & Oranye & $\begin{array}{l}\text { Tidak } \\
\text { mengandung } \\
\text { senyawa fenol }\end{array}$ \\
\hline Ekstrak & $\begin{array}{l}\text { Hijau } \\
\text { kehitaman }\end{array}$ & $\begin{array}{l}\text { Mengandung } \\
\text { senyawa fenol }\end{array}$ \\
\hline
\end{tabular}

Uji pendahuluan dilakukan untuk menunjukkan adanya senyawa aktif yang terkandung di dalam ekstrak secara umum. Hasil perlakuan menunjukkan bahwa ekstrak etanol positif mengandung flavonoid, tanin, saponin, senyawa fenol, polifenol, dan alkaloid. Berdasarkan hasil perlakuan tersebut maka daun pare positif mengandung flavonoid, tanin, saponin, fenolik, polifenol, dan alkaloid. Hasil perlakuan ini sesuai dengan penelitian yang pernah dilakukan oleh Rachmawati, dkk. (2001) dan Leelaprakash, dkk. (2011) yang menyatakan bahwa daun pare positif mengandung flavonoid, tanin, saponin, senyawa fenol, polifenol, dan alkaloid.

Selain uji pendahuluan dengan pereaksi kimia, uji senyawa flavonoid juga dilakukan dengan metode kromatografi lapis tipis (KLT).Fase diam yang digunakan adalah silika gel $\mathrm{GF}_{254}$ dan fase gerak $n$ butanol : asam asetat : akuades (4:1:5), jarak elusi $8 \mathrm{~cm}$, dan penampak bercak uap ammonia. Baku pembanding rutin digunakan untuk melihat perbandingan nilai Rf. Flavonoid yang bersifat polar terikat kuat pada fase diam. Dengan adanya fase gerak yang bersifat semi polar akan membawa flavonoid melewati fase diam dan akan memisah. Adanya uap ammonia akanmenyebabkan gugus hidroksi fenolik pada flavonoid membentuk warna kuning.

Hasil identifikasi pada ekstrak, fraksi etil asetat, dan fraksi air ekstrak etanol daun pare menunjukkan terjadinya fluoresensi warna ungu saat dilihat di bawahsinar UV $254 \mathrm{~nm}$ dan terbentuk noda berwarna kuning lemah setelah diberi uap ammonia.
Sedangkan fraksi $n$-heksan tidak menunjukkan adanya fluoresensi warna ungu maupun noda kuning setelah diberi uap ammonia. Harga $\mathrm{Rf}$ yang diperoleh untuk ekstrak yaitu 0,61 dan baku rutin 0,57 (tabel 13), sehingga dapat disimpulkan bahwa pada ekstrak etanol daun pare mengandung flavonoid.

\section{Tabel 13.Hasil Identifikasi Flavonoid Secara KLT}

\begin{tabular}{|c|c|c|}
\hline Larutan Uji & Rf & $\begin{array}{c}\text { Warna } \\
\text { tampak } \\
\text { dengan } \\
\text { amoniak }\end{array}$ \\
\hline Baku rutin & 0,57 & $\begin{array}{c}\text { Kuning } \\
\text { kecoklatan }\end{array}$ \\
\hline Ekstrak & 0,61 & Kuning lemah \\
\hline
\end{tabular}

Pengukuran kadar glukosa dilakukan dengan membuat larutan baku glukosa. Serbuk glukosa anhidrat yang sudah ditimbang dilarutkan dengan etanol $80 \%$ panas, kemudian diuapkan terlebih dahulu sebelum dicukupkan dengan akuades. Penambahan etanol $80 \%$ panas berfungsi untuk mencegah pertumbuhan mikroba karena glukosa dapat menjadi nutrisi yang baik untuk pertumbuhan mikroba. Larutan glukosa selanjutnya diuapkan untuk mengurangi jumlah etanol. Larutan glukosa dibuat konsentrasi 2000 ppm, kemudian diencerkan menjadi $100 \mathrm{ppm}$. Deret baku glukosa dibuat dengan konsentrasi 10, 20, 30, 40, dan $50 \mathrm{ppm}$. Masing-masing konsentrasi baku glukosa direaksikan dengan reagen Nellson, kemudian diukur absorbansinya. Pengukuran kadar glukosa menggunakan spektrofotometri visibel karena senyawa yang akan diukur berupa larutan berwarna yang dapat diserap pada panjang gelombang $400 \mathrm{~nm}$ sampai $750 \mathrm{~nm}$. Pengukuran panjang gelombang maksimal dilakukan setelah didapatkan operating time.

Panjang gelombang maksimal yang diperoleh pada menit ke-11 adalah $761 \mathrm{~nm}$, sehingga pengukuran baku glukosa anhidrat dilakukan pada menit ke-11 dengan panjang gelombang $761 \mathrm{~nm}$. 
Deret konsentrasi larutan baku glukosa anhidrat 10, 20, 30, 40, dan $50 \mathrm{ppm}$ ditambahkan dengan reagen Nellson. Penambahan reagen tersebut dapat mereduksi kuprioksida menjadi kuprooksida ekuivalen dengan jumlah glukosa yang ada. Adanya sifat mereduksi disebabkan oleh adanya gugus aldehid bebas yang terdapat dalam glukosa. Selanjutnya glukosa mengalami oksidasi oleh pereaksi Nellson menghasilkan asam glukonat. Larutan dipanaskan dengan ditutup kapas agar reaksi berlangsung secara maksimal. Dengan adanya pemanasan dapat meningkatkan energi kinetik dari molekulmolekul sehingga akan meningkatkan kecepatan reaksi. Larutan yang sudah dipanaskan selanjutnya didinginkan dan ditambah reagen arsenomolibdat didapatkan warna biru kehijauan karena arsenomolibdat bereaksi dengan kuprooksida membentuk molibdenum. Pengukuran dilakukan pada saat operating timedengan panjang gelombang $761 \mathrm{~nm}$.Kurva baku glukosa anhidrat dapat dilihat pada gambar 9 .

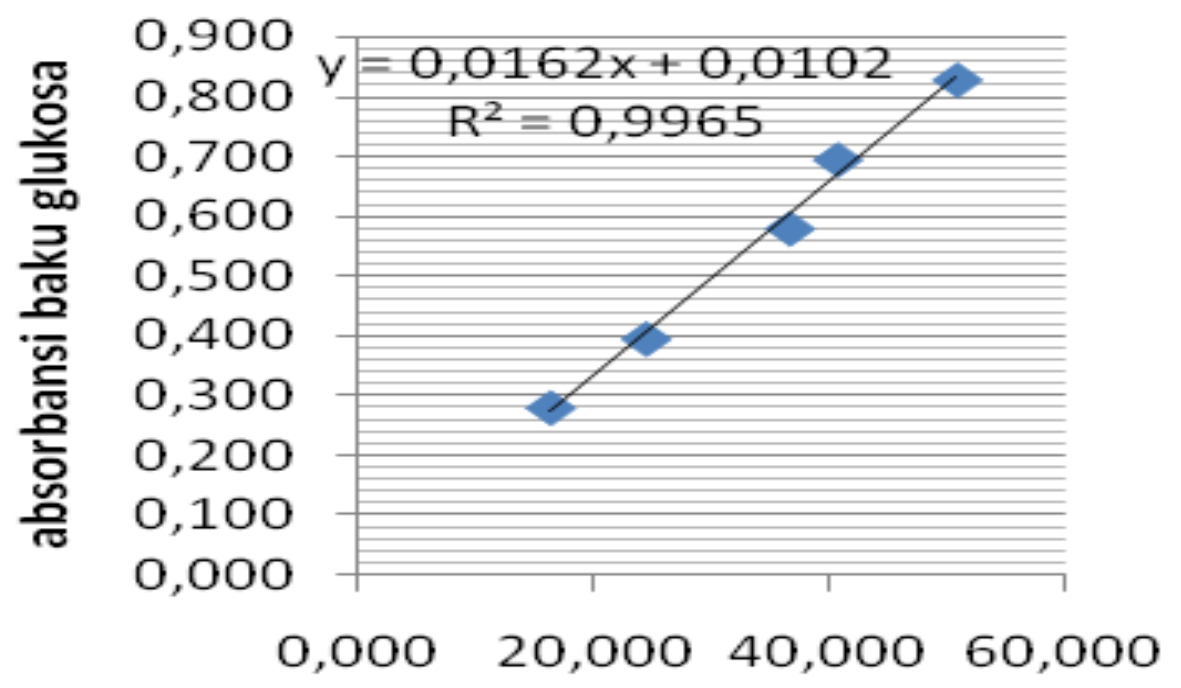

konsentrasi baku glukosa (ppm)

\section{Gambar 9.Kurva Baku Glukosa Anhidrat}

Konsentrasi larutan baku glukosa yang digunakan dalam penelitian ini $50 \mathrm{ppm}$. Masing-masing konsentrasi ditambahkan dengan baku glukosa, kemudian dari campuran tersebut diambil sebanyak 1,0 mL untuk direaksikan dengan reagen Nellson. Larutan dipanaskan dengan ditutup kapas, lalu didinginkan, dan ditambahkan dengan arsenomolibdat, kemudian larutan diukur pada saat operating time dengan panjang gelombang $761 \mathrm{~nm}$.

Hasil data penurunan kadar glukosa menunjukkan rata-rata persentase penurunan yang terus meningkat dari $80 \mathrm{ppm}$ sampai 160 ppm. Pada konsentrasi. Persentase penurunan paling tinggi pada konsentrasi 160 ppm dengan rata-rata 50,38 
Tabel 16. Hasil Perhitungan PersenPenurunan Glukosa

\begin{tabular}{|c|c|c|c|c|}
\hline \multirow{2}{*}{$\begin{array}{c}\text { Konsentrasi } \\
(\mathrm{ppm})\end{array}$} & \multicolumn{3}{|c|}{ \% penurunan glukosa } & $\begin{array}{c}\text { Rata-rata \% } \\
\text { penurunan } \\
\text { glukosa }\end{array}$ \\
\cline { 2 - 4 } & Replikasi 1 & Replikasi 2 & Replikasi 3 & $11,55 \%$ \\
\hline 80 & $10,81 \%$ & $11,18 \%$ & $12,66 \%$ & $23,96 \%$ \\
\hline 100 & $23,84 \%$ & $23,96 \%$ & $24,08 \%$ & $35,80 \%$ \\
\hline 120 & $36,25 \%$ & $35,76 \%$ & $35,39 \%$ & $45,14 \%$ \\
\hline 140 & $44,85 \%$ & $45,22 \%$ & $45,34 \%$ & $50,38 \%$ \\
\hline 160 & $49,77 \%$ & $50,63 \%$ & $50,75 \%$ & \\
\hline
\end{tabular}

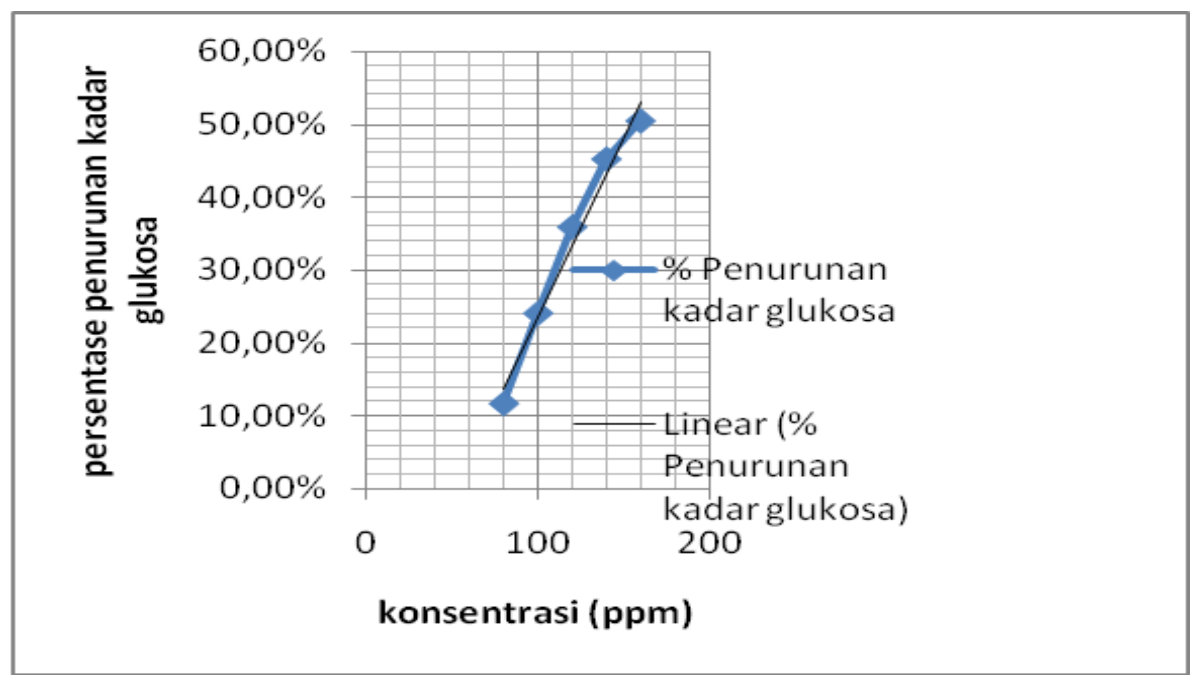

\section{Gambar 10. Kurva Penurunan Kadar Glukosa}

Pada grafik tersebut dapat diketahui bahwa persentase penurunan kadar glukosa lebih besar pada kadar 160 ppm dibandingkan dengan kadar 80 ppm

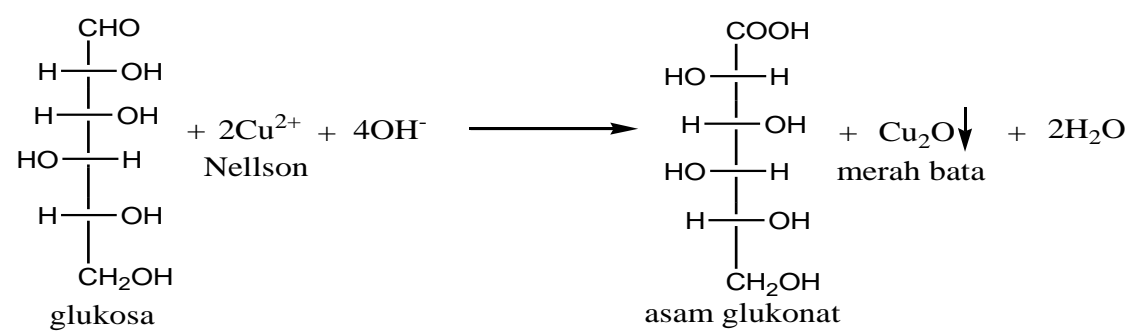

$\left(\mathrm{NH}_{4}\right)_{6} \mathrm{Mo}_{7} \mathrm{O}_{24} \cdot 4 \mathrm{H}_{2} \mathrm{O}+3 \mathrm{H}_{2} \mathrm{SO}_{4} \longrightarrow 7 \mathrm{H}_{2} \mathrm{MoO}_{4}+3\left(\mathrm{NH}_{4}\right)_{2} \mathrm{SO}_{4}$

$12 \mathrm{MoO}_{4}{ }^{2-}+\mathrm{AsO}_{4}{ }^{3-}$

$\left[\mathrm{AsMo}_{12} \mathrm{O}_{40}\right]+12 \mathrm{H}_{2} \mathrm{O}$

(3).

$\left[\mathrm{AsMo}_{12}{ }^{\mathrm{V}} \mathrm{O}_{40}\right]^{3-}+4 \mathrm{Cu}^{+}$ $\left[\mathrm{AsMo}_{4}{ }^{\mathrm{V}} \mathrm{Mo}_{8}{ }^{\mathrm{VI}} \mathrm{O}_{40}\right]^{7-}+4 \mathrm{Cu}^{2+}$

Gambar 11. Reaksi Pembentukan Senyawa Kompleks Glukosa dengan Arsenomolibdat (Kautsar, 2011) 
Kompleks molibdenum yang terukur sebanding dengan kadar glukosa dalam larutan. Komponen warna dari pereaksi Nellson-Somogyi juga akan mengabsorbsi cahaya pada panjang gelombang $747 \mathrm{~nm}$, sehingga dalam analisis ini digunakan blangko dengan menambahkan pereaksi tersebut. Hal ini bertujuan untuk meminimalkan adanya peningkatan absorban yang terukur oleh instrumen yang berasal dari warna senyawa yang tidak diharapkan, yang mengakibatkan penurunan akurasi pengukuran.

Analisis data penelitian secara statistik dengan menggunakan SPSS (Statistical Product and Service Solutions) versi 16 didahului dengan uji normalitas dengan menggunakan rumus dari Shapiro-Wilk, dan uji homogenitas dengan menggunakan rumus dari Lavene Test. Untuk uji normalitas dan uji homogenitas nilai signifikansi lebih besar dari 0,05. Uji normalitas digunakan untuk mengetahui apakah data berdistribusi normal atau tidak, sedangkan uji homogenitas digunakan untuk mengetahui apakah ragam antar perlakuan homogen atau tidak.

Berdasarkan perhitungan dari uji Tukey antar kelompok glukosa setelah penambahan data berbeda signifikan yaitu nilai signifikansinya kurang dari 0,05 , sehingga dapat disimpulkan masing-masing kelompok data terdapat perbedaan dalam menurunkan kadar glukosa.

Tabel 19. Data Interpretasi Spektrum UVVis

\begin{tabular}{|c|c|c|c|c|c|}
\hline \multirow{2}{*}{$\begin{array}{l}\text { Perlakuan } \\
\text { Sampel } \\
\text { Isolat } \\
\text { Flavonoid }\end{array}$} & \multicolumn{2}{|c|}{$\lambda$ maks (nm) } & \multicolumn{2}{|c|}{$\begin{array}{c}\text { Pergesera } \\
\text { n } \lambda(\mathbf{n m})\end{array}$} & \multirow{2}{*}{$\begin{array}{c}\text { Penafsir } \\
\text { an }\end{array}$} \\
\hline & $\begin{array}{c}\text { Pita } \\
\text { I }\end{array}$ & $\begin{array}{c}\text { Pita } \\
\text { II }\end{array}$ & $\begin{array}{l}\text { Pit } \\
\text { a I }\end{array}$ & $\begin{array}{l}\text { Pit } \\
\text { a II }\end{array}$ & \\
\hline $\begin{array}{c}\text { Sampel } \\
\text { dalam } \\
\text { metanol }\end{array}$ & $\begin{array}{c}366, \\
4\end{array}$ & 271,2 & - & - & $\begin{array}{l}\text { Flavonol } \\
\text { (3-OH } \\
\text { bebas) }\end{array}$ \\
\hline $\begin{array}{c}\text { Sampel } \\
\text { dalam } \\
\text { metanol + } \\
\mathrm{NaOH}\end{array}$ & $\begin{array}{c}343 \\
4\end{array}$ & 266,2 & -23 & -5 & $\begin{array}{l}\text { 3,4'-OH, } \\
o \text {-diOH } \\
\text { pada } \\
\text { cicin A, } \\
\text { pada } \\
\text { cincin B } \\
: 3 \text {-OH } \\
\text { berdampi }\end{array}$ \\
\hline
\end{tabular}

Pada spektrum yang ditunjukkan pada sampel yang dilarutkan dalam metanol didapatkan dua pita yaitu pita I pada panjang gelombang 366,4 nm dan pita II pada panjang gelombang $271,2 \mathrm{~nm}$. Interpretasi spektrum pada kedua pita di atas adalah rentang spektrum dari senyawa flavonoid golongan flavonol.Penambahan pereaksi geser $\mathrm{NaOH}$ untuk mendeteksi adanya gugus hidroksil yanglebih asam, yang pada hasil diperoleh gugus hidroksil pada rantai karbon 4'.Penambahan kekuatan spektrum setelah waktu tertentu menunjukkan bahwa gugus ini tidak peka terhadap basa.Penambahan pereaksi geser $\mathrm{Na}$ asetat digunakan untuk mendeteksi adanya gugus 7-hidroksil bebas.Pada hasil tidak didapatkan bahwa terkandung adanya gugus 7-hidroksil bebas.Penambahan $\quad \mathrm{H}_{3} \mathrm{BO}_{3}$ untuk menjembatani kedua gugus hidroksil $o$-diOH, pada hasil menunjukkan adanya gugus $o$ diOH pada cincin B. Penambahan pereaksi geser $\mathrm{AlCl}_{3}$ dan $\mathrm{HCl}$ untuk mendeteksi adanya gugus 5-hidroksil bebas. Pada hasil didapatkan bahwa terkandung adanya gugus 5-hidroksil bebas. 
Hasil yang didapat dari interpretasi spektrum di atas adalah 5, 3', 4' - trihidroksi flavonol.<smiles>O=c1c(O)c(-c2ccc(O)c(O)c2)oc2cccc(O)c12</smiles>

Gambar 12.Interpretasi spektrum flavonoid 5, 3', 4'-trihidroksi flavonol

\section{KESIMPULAN}

1. Kondisi yang optimum dalam proses ekstraksi flavonoid dari daun pare (Momordica charantiaL.) dengan berbantu gelombang mikroadalahmenit ke-30 dengan rendemen $20,85 \%$.

2. Konsentrasi ekstrak flavonoid yang dapat menurunkan kadar glukosa adalah $160 \mathrm{ppm}$ dengan penurunan $50,38 \%$.

3. Jenis flavonoid dalam daun pare (Momordica charantia L.) yang dapat menurunkan kadar glukosaadalah 5, 3', 4'-trihidroksi flavonol

\section{SARAN}

1. Dilakukan penelitian lebih lanjut mengenai uji aktivitas isolat flavonoid daun pare (Momordica charantia L.) dalam menurunkan kadar glukosa secara in vitro.

2. Dilakukan penentuan kadar flavonoid total pada isolat daun pare (Momordica charantia L.) dalam menurunkan kadar glukosa secara invitro.

\section{DAFTAR PUSTAKA}

Ahmad Z., Khairul F.Z., Azhar Y., Chiong H.S., Malarvilis S., Amin I., dan analysis of Polipeptide-K and Oil Isolated from Seeds of Momordica charantia (Bitter Gourd).l Journal Molecules. 17. 9631-9640.

Muhammad N.H. 2012. In Vitro Antidiabetic Activities and Chemical

Basha S. K. dan Kumari. 2012. In Vitro Antidiabetic Activity of Psidium Guajava Leaves Extracs, Asian Pasific Journal of Tropical Disease. $1-3$

Departemen Kesehatan RI. 1986. "Sediaan Galenik". Jakarta: Depkes RI

Ermaiza. 2009. Pengaruh Dua Jenis Polisakarida dalam Biji Alpukat (Persea americana mill) Terhadap Kandungan Sirup Glukosa Melalui Proses Hidrolisis dengan $\mathrm{HCl} \mathbf{3 \%}$. Skripsi. Medan: Fakultas Matematika dan Ilmu Pengetahuan Alam Universitas Sumatera Utara

Hardiman, D. 2013. Diabetes dan Komplikasinya Mengintai Kelengahan Kita. Tumbuh. Edisi Januari: 3-5.

Heinrich, M., Joanne B., Simon G., dan Elisabeth M. W. 2009. Farmakognosi dan Fitoterapi. Diterjemahkan oleh Amalia H. Hadinata. Jakarta: Buku Kedokteran EGC.

Kautsar, R. H. 2011. Kajian Hidrolisis Enzimatis Selulosa dari Alga Merah (Eucheuma spinosum dan Eucheuma cottoni) Menggunakan Enzim Selulase dari Aspergillus niger. Skripsi. Malang: Fakultas Sains dan Teknologi Universitas Islam Negeri Maulana Malik Ibrahim

Leelaprakash, G., J. Caroline, Gowtham B.M., Pradeep K., dan Shivram P. 2011. In Vitro Antimicrobial and Antioxidant Activity of Momordica charantia Leaves. Pharmacophore. 2. (4) : 242-252 
METANA, Vol. 10 No.01, Juli 2014, Hal. 1-11

Purwatresna, E. 2012. Aktivitas Antidiabetes Ekstrak Air dan Etanol Daun Sirsak Secara in vitro melalui inhibisi enzim $\alpha$ glukosidase. Skripsi. Bogor: Institut Pertanian Bogor

Razak A. K., Ni Ketut Sumarni, Basuki Rahmat. 2012. Optimasi Hidrolisis Sukrosa Menggunakan Resin Penukar Kation Tipe Sulfonat. Jurnal Natural Science 1 (1):119-131

Robinson, T. 1995. Kandungan Organik Tumbuhan Tingkat Tinggi. Terjemahan Padmawinata, K. Bandung: ITB Press.

Sadasivam, S. dan Manickam, A. 1996. Biochemical Methods. New Delhi: New Age International

Zaini, R. 2006. Isolasi Komponen Bioaktif Flavonoid dari Tanaman Daun Dewa (Gynura pseudochina L.). Tesis. Bogor: Institut Pertanian Bogor. 